\title{
The unseen majority of \\ microorganisms in hadal trenche sediments revealed by molecular and biogeochemical techniques
}

YUli WeI ${ }^{1}$, Xi Nie ${ }^{2}$, Li Zhang ${ }^{2}$, HUIMIN YAO ${ }^{2}$, HAIYAN MAO ${ }^{1}$, JIASONG FANG $1,3,4 *$

${ }^{1}$ Shanghai Engineering Research Center of Hadal Science and Technology, College of Marine Sciences, Shanghai Ocean University, Shanghai 201306, PR China

${ }^{2}$ State Key Laboratory of Geological Processes and Mineral Resources, Faculty of Earth Sciences, China University of Geosciences, Wuhan 430074, PR China

${ }^{3}$ Laboratory for Marine Biology and Biotechnology, Qingdao National Laboratory for Marine Science and Technology, Qingdao 266237, PR China

${ }^{4}$ Department of Natural Sciences, Hawaii Pacific University, Honolulu, HI 96813

Endospores are bacterial resting stages and can survive for millions of years and may thus accumulate in trench sediments. The number of endospores in trench sediments has never been quantified because of methodological problems, and consequently little is known about the quantitative distribution of endospores in the deep marine subsurface. Here we report a new analytical method to determine the number of endospores in sediment from three different trenches in the western Pacific (New Britain Trench; Mariana Trench, and Mussau Trench). The method is based on quantification of dipicolinic acid (DPA, pyridine-2,6dicarboxylic acid), a spore core-specific compound. Bacillus subtilis $168^{\mathrm{T}}$ was used to determine the quantitative relationship between the content of DPA and the number of endospores in trench sediments. Our results show that the number of endospores ranged from $2.24 \times 10^{5}$ to $9.36 \times 10^{6}$ spores $\mathrm{g}^{-1}, 1.47 \times 10^{6}$ to $3.98 \times 10^{6}$ spores $\mathrm{g}^{-1}$, and $2.01 \times 10^{6}$ to $2.80 \times 10^{6}$ spores $^{-1}$ dry weight of sediment in New Britain Trench, Mariana Trench, and Mussau Trench, respectively. The abundance of bacterial endospores decreased with depth in all sediments. Furthermore, bacteria endospore was as abundant as bacterial vegetative cells. These findings suggest that bacterial endospores may play a role in biogeochemical cycles in the deep marine subsurface. 